\title{
ROZWÓJ PROFESJONALNY DYREKTORA SZKOŁY - PRZESŁANKI DLA ROZWIĄZAŃ INSTYTUCJONALNYCH
}

\begin{abstract}
Rosalska Małgorzata, Rozwój profesjonalny dyrektora szkoty - przesłanki dla rozwiazań instytucjonalnych [Professional Development of the School Principal - Premises for Institutional Solutions]. Studia Edukacyjne nr 42, 2016, Poznań 2016, pp. 205-216. Adam Mickiewicz University Press. ISSN 1233-6688. DOI: 10.14746/se.2016.42.12

The goal of this article is to reflect on the relationship between theoretical assertions of leadership in education and practical solutions for the education of human resources in the management of education. There are being analyzed proposals for institutional development opportunities that determine the effective performance of tasks, both managerial and leadership ones, assigned to the school principal. To this end, the current forms of professional development offered to school principals and the theoretical underpinnings of the system for promoting the professional development of school community leaders are presented.
\end{abstract}

Key words: educational leadership, professional development, school principal

Przywództwo $\mathrm{w}$ edukacji to temat często powiązany $\mathrm{z}$ zagadnieniem kształcenia kadr do zarządzania oświatą. Jest to jednak ujęcie wąskie i ograniczające możliwości analizowania przywództwa w kontekście innych, niż tylko menedżerskie, procesów. Jeśli przyjąć szeroką definicję przywództwa, rozumianego jako „skomplikowany proces społeczny, który sprzyja osiąganiu przez jednostki i grupy określonego celu"1, to namysł nad preferowanym profilem kompetencyjnym dyrektora szkoły i edukacyjnymi możliwościami jego kształtowania, rozwijania i wzmacniania staje się zdecydowanie szerszy i ciekawszy niż w przypadku, gdy akcent położony jest głównie na kwestie związane z zarządzaniem placówkami edukacyjnymi.

${ }^{1} \mathrm{~J}$. Madalińska-Michalak, Skuteczne przywództwo w szkołach na obszarach zaniedbanych społecznie. Studium porównawcze, Łódź 2012, s. 65. 
Tony Bush definiuje przywództwo na gruncie edukacji poprzez wskazanie trzech konstytutywnych dla niego wymiarów. W jego ujęciu stanowi ono proces wpływania, jest powiązane $\mathrm{z}$ wartościami oraz opiera się na wizji2 Wpływ oznacza, iż przywództwo występuje zawsze $w$ relacji społecznej i może dotyczyć zarówno działań, jak i relacji. Wyraża, iż nie jest ono zależne od sprawowanej funkcji, ale też niezależne od formalnego autorytetu. Drugi aspekt to intencjonalność. Działania podejmowane przez przywódcę zawsze powinny być ukierunkowane na realizację uprzednio założonych celów. Trzecia wyróżniona przez Busha cecha wpływu to możliwość jego rozwijania zarówno przez jednostki, jak i grupy ${ }^{3}$. W kontekście podjętego w niniejszym opracowaniu tematu są to założenia istotne. Ukierunkowują one refleksję na poszukiwanie strategii i metod rozwijania tych kompetencji, które będą sprzyjały realizowaniu powyższych postulatów w szkolnej codzienności. Mając na uwadze, iż dyrektor szkoły to nie tylko osoba zarządzająca zasobami i procesami, można zastanawiać się nad rzeczywistymi możliwościami organizowania ofert edukacyjnych sprzyjających rozwijaniu tych kompetencji, które warunkują efektywne działania dyrektora także w rolach lidera, przywódcy, animatora czy facylitatora.

Rozważania podjęte $\mathrm{w}$ tym opracowaniu sytuuję w kontekście rozpoznawania ofert edukacyjnych proponowanych w ramach formalnych możliwości zdobywania kwalifikacji i rozwijania kompetencji do pełnienia roli dyrektora szkoły. Jednocześnie, chcę wyraźnie zaznaczyć, iż rozwój zawodowy, profesjonalny dyrektora szkoły postrzegam jako wypadkową dwóch aktywności. Pierwszą jest intencjonalnie planowana i realizowana aktywność edukacyjna, drugą - uważność i refleksyjność na temat własnej praktyki realizowanej w szkolnej codzienności.

Warto zauważyć, iż preferowane założenia co do roli dyrektora w szkole mają bezpośrednie przełożenie na praktykę edukacyjną przynajmniej w dwóch wymiarach. Pierwszym jest sposób formułowania kryteriów oceny kandydata na stanowisko dyrektora, a w dalszej perspektywie oceny sposobu jego pracy. Drugi to programy kształcenia adresowane do kandydatów na kierownicze stanowiska w placówkach edukacyjnych. Można przyjąć, iż programy te są egzemplifikacją uprzednio przyjętych założeń na temat wiedzy, umiejętności i kompetencji społecznych dyrektora. Analiza możliwości rozwoju profesjonalnego dyrektora szkoły zaproponowana $\mathrm{w}$ niniejszym artykule nawiązuje do drugiego ze wskazanych wymiarów. Refleksja dotyczyć będzie rozwiązań w zakresie instytucjonalnych propozycji rozwijania

2 T. Bush, Theories of Educational Leadership and Management, London 2011, s. 5-7.

${ }^{3}$ T. Bush, From management to leadership: semantic or meaningful change? Educational Management, Administration and Leadership, 2008, 36(2), s. 277. 
kompetencji warunkujących efektywne realizowanie zadań przypisanych dyrektorowi szkoły, zarówno $\mathrm{w}$ ramach funkcji menedżerskich, jak i przywódczych. W tym celu zaprezentowane zostaną zarówno aktualnie oferowane dyrektorom formy rozwoju zawodowego, jak i przesłanki teoretyczne leżące u podstaw systemu wspierania rozwoju zawodowego osób przewodzących szkolnym społecznościom.

Kształcenie liderów w zakresie zarządzania oświatą realizowane jest przede wszystkim poprzez studia podyplomowe i kursy kwalifikacyjne. Tę formę kształcenia reguluje Rozporządzenie Ministra Edukacji Narodowej z 8 listopada $2011 \mathrm{roku}^{4}$.

Studia projektowane i adresowane są przede wszystkim do osób aspirujących do roli dyrektora szkoły. Układ treści oraz formy ich realizacji ukierunkowane są na budowanie kompetencji bazowych, podstawowych, zarówno w obszarze wiedzy jak i umiejętności. Jednocześnie warto odnotować, iż układ, jak i zakres treści wyraźnie warunkowane są specyfiką uczelni, która takie studia oferuje. Nawet pobieżna analiza programów studiów podyplomowych $\mathrm{w}$ dziedzinie zarządzania oświatą pozwala stwierdzić, że ich program jest warunkowany specjalizacją uczelni. Inne treści, a przynajmniej proporcje między nimi, proponowane są na wydziałach pedagogicznych, inne zaś na uczelniach ekonomicznych. Nieco odmiennie postrzegać można program kursów kwalifikacyjnych z zakresu zarządzania oświatą. Ta oferta realizowana jest przez placówki doskonalenia nauczycieli, a jej program zatwierdzany przez Ministerstwo Edukacji Narodowej. W świetle obecnie obowiązującego programu, kurs kwalifikacyjny z dziedziny zarządzania oświatą obejmuje sześć obszarów tematycznych, jak: przywództwo edukacyjne w szkole, przywództwo dla uczenia się i rozwoju indywidualnego, polityka oświatowa - dyrektor jako lider w środowisku, zarządzanie zasobami ludzkimi, zarządzanie strategiczne $\mathrm{w}$ kontekście prawnym, społecznym i finansowym oraz zarządzanie własnym rozwojem zawodowym ${ }^{5}$.

W literaturze przedmiotu można spotkać krytykę dotychczasowych rozwiązań. Warto przywołać tu refleksje Szymona Więsława, który na podstawie analizy i oceny dostępnych ofert w zakresie kształcenia dyrektorów oraz $\mathrm{w}$ odniesieniu do danych empirycznych zaproponował rozwiązania

${ }^{4}$ Rozporządzenie Ministra Edukacji Narodowej z dnia 8 listopada 2011 roku zmieniające rozporządzenie $w$ sprawie wymagań, jakim powinna odpowiadać osoba zajmująca stanowisko dyrektora oraz inne stanowisko kierownicze w poszczególnych typach publicznych szkół i rodzajach publicznych placówek (DzU 2011, 254, 1526)

${ }^{5}$ Ministerstwo Edukacji Narodowej, Ramowy plan i program kursu kwalifikacyjnego z zakresu zarządzania oświatą, https://men.gov.pl/wp-content/uploads/2015/11/zatwierdzona-ramo wka-kursu-z-zarzadzania-oswiata-w-pdf.pdf [data dostępu: 02.01.2017]. 
dotyczące budowy nowego systemu kształcenia zawodowego dyrektorów oraz rozwiązań sprzyjających mobilności zawodowej. Ta rekomendacja wynika $\mathrm{z}$ rozpoznanej $\mathrm{w}$ badaniach zrealizowanych przez autora stabilności zatrudnienia dyrektorów i niewielkiego doświadczenia tej grupy zawodowej w pracy poza kierowaną placówką. Autor pisze wprost o naglącej potrzebie stworzenia rozwiązań sprzyjających mobilności zawodowej dyrektorów. Rozwiązania te proponuje w dwóch perspektywach. Pierwsza z nich to możliwości prawne, które mogłyby wzmacniać mobilność zawodową dyrektorów na przykład poprzez takie regulacje, jak ograniczenie czasu pełnienia funkcji dyrektora $\mathrm{w}$ danej placówce do dwóch kadencji lub zakaz pełnienia funkcji kierowniczej w placówce, w której uprzednio dyrektor pracował jako nauczyciel. Te, mocno dyskusyjne, rozwiązania łączą się z postulatem i potrzebą transferu wiedzy i doświadczeń. Druga perspektywa uwzględnia edukacyjne mechanizmy stymulowania kompetencji zawodowych związanych z realizacją funkcji i roli dyrektora szkoły. Z badań wynika, iż większość dyrektorów nie ma wcześniejszego doświadczenia $\mathrm{w}$ zakresie zarządzania. W związku z tym autor proponuje budowę nowego systemu kształcenia i doskonalenia dyrektorów, który byłby oparty na rozwiązaniach stosowanych w projektowaniu i organizacji studiów menedżerskich. Swoją propozycje postrzega jako rozwiązanie dwuetapowe. Pierwszy etap, teoretyczny, miałby być zbliżony do aktualnie proponowanych studiów podyplomowych $\mathrm{z}$ zakresu zarządzania oświatą. Byłaby to oferta obowiązkowa dla wszystkich, którzy chcą podjąć się zadań kierowania szkołą lub inną placówką edukacyjną. Drugi etap, praktyczny, to propozycja dedykowana wszystkim dyrektorom $\mathrm{w}$ okresie dwóch pierwszych lat od objęcia po raz pierwszy stanowiska. Wzorem dla tego rozwiązania są studia podyplomowe typu MBA, których celem jest wzmocnienie praktycznych kompetencji w dziedzinie realizacji zadań, wymiana doświadczeń i mocne powiązanie z praktyką ${ }^{6}$.

Odnosząc się do tej propozycji, można jednak zauważyć, iż utrwala ona menedżerską perspektywę postrzegania kompetencji dyrektora szkoły, akcentując zarządczy aspekt jego roli. W odniesieniu do współczesnego dyskursu w obszarze przywództwa w edukacji warto zastanowić się nad przesłankami, które mogą inaczej ukierunkowywać aktualne dyskusje związane z kształceniem liderów procesów edukacyjnych. $W$ dalszej części tego opracowania chcę odnieść się do trzech wybranych założeń, które mogą stać się podstawą do namysłu nad edukacyjnymi projektami kształcenia edukacyjnych lide-

${ }^{6}$ S. Więsław, Sytuacja i status zawodowy dyrektorów szkót i placówek oświatowych, Warszawa 2012, s. 25. 
rów. Założenia te dotyczą ewolucji postrzegania roli dyrektora szkoły, sfer rozwoju zawodowego oraz możliwości rozwijania kapitału profesjonalnego.

Koncepcje przywództwa kształtowały się i ewoluowały wraz ze zmianami społeczno-ekonomicznymi oraz rozwojem nauk o organizacji i zarządzaniu, psychologii społecznej oraz socjologii. Sposób definiowania ról i zadań dyrektora szkoły także uległ wyraźniej ewolucji. Podstawowym kierunkiem tych zmian jest, jak zauważa Zbyszko Melosik, wyraźne przejście od administracyjnego kierowania szkołą do modelu opartego na zarządzaniu oraz przywództwie edukacyjnym ${ }^{7}$. Philip Hallinger wskazał trzy główne fazy definiowania koncepcji sprawowania ról i zadań dyrektora szkoły. Podział ten nawiązuje to sytuacji dyrektorów szkół amerykańskich. Warto jednak go przywołać, ponieważ ukazuje relację pomiędzy dominującymi ideologiami a elementami zawodowego profilu preferowanego dyrektora. Pierwsza faza obejmuje lata 60. i 70. XX wieku. Dominowało wówczas menedżerskie postrzeganie roli dyrektora. Jego zadaniem było sprawne implementowanie zaprojektowanych $\mathrm{w}$ innych ośrodkach decyzyjnych założeń na temat priorytetów w edukacji i preferowanych form ich realizacji. W szkołach publicznych zadaniem dyrektora było takie administrowanie placówką, aby jak najlepiej wypełniać założenia polityki oświatowej. Dyrektor był urzędnikiem, administratorem, zarządcą . Druga faza rozpoczęła się w połowie lat 80 . XX wieku. Dominującą koncepcją stało się wówczas przywództwo instruktażowe (instructional leadership). Ta "nowa ortodoksja” przekierowała uwage na rolę dyrektora już nie jako menedżera, ale także jako lidera9 ${ }^{9}$. Dyrektor zaczął być postrzegany jako podstawowe źródło wiedzy o możliwościach rozwijania szkolnej oferty i zapewnienia efektywności realizowanych w szkole programów. W jego profilu kompetencyjnym zaczęto wskazywać wiedzę i umiejętności związane z nauczaniem, wychowaniem i monitorowaniem zarówno działań nauczycieli, jak i wyników uczniów. Zadania dyrektora opisywano $\mathrm{w}$ kategoriach monitorowania, koordynowania, instruowania, nadzorowania. Trudności sprawiało jednak zaprojektowanie oferty edukacyjnej dla dyrektorów, która w swych założeniach ukierunkowana miała być na rozwijanie kompetencji w zakresie przywództwa instruktażowego. Jak zauważa Hallinger, w analizowanym okresie były opracowywane programy doskonalenia dla kadry kierowniczej szkól, jednak - jak podkreślali analitycy tych procesów - programy tych ofert były mocno zakotwi-

${ }^{7}$ Z. Melosik, Systemy kształcenia i doskonalenia kadry kierowniczej w krajach Unii Europejskiej i Stanach Zjednoczonych, Warszawa 2014, s. 6.

8 P. Hallinger, The evolving role of American principals: From managerial to instructional to transformational leaders, Journal of Educational Administration, 1992, 30, 3.

${ }_{9}$ Tamże. 
czone w indywidualnych preferencjach i doświadczeniach autorów. Poszukiwanie algorytmów działania skutecznego dyrektora okazywało się trudne do zrealizowania. Efektywność pracy szkoły nie była bowiem zależna wyłącznie od kompetencji dyrektora. Istotną rolę odgrywały także czynniki środowiskowe ${ }^{10}$. Trzecia $\mathrm{z}$ wyróżnionych faz to lata 90 . i dominacja koncepcji przywództwa transformacyjnego. To podejście opierało się na założeniu, że szkoła jest przestrzenią inicjowania zmian, a nie tylko ich implementowania. Istotną przesłanką było tu także uznanie znaczenia decentralizacji i podmiotowości poszczególnych szkół. Te założenia doprowadziły do większego zabiegania przez dyrektorów o zaangażowanie nauczycieli i innych partnerów społecznych $\mathrm{w}$ procesy identyfikacji kluczowych problemów i działań ukierunkowanych na realizację celów zdefiniowanych jako priorytetowe ${ }^{11}$.

Zaproponowany przez Hallingera podział pozwala stwierdzić, iż zasadniczymi czynnikami dynamizującymi ewolucję postrzegania roli dyrektora szkoły są dominujące ideologie edukacyjne oraz stopień centralizacji oświaty. Im bardziej jest ona scentralizowana, tym wyraźniej preferowany będzie menedżerski lub nawet administracyjny model pełnienia tej roli. Jacek Pyżalski zaznacza także, że sposób definiowana roli dyrektora zależy od tradycji i uwarunkowań społeczno-kulturowych w danym kraju12. Zależność ta dotyczy również polskiego systemu edukacji. Analizując kierunki zmian w zarządzaniu oświatą, Stefan M. Kwiatkowski wyróżnił dwa zjawiska, które w największym stopniu warunkowały ich charakter. Autor ten wskazał na decentralizację oraz na uspołecznienie procesu podejmowania decyzji13. Zmiany te wymusiły ewolucję postrzegania roli i zadań przypisanych dyrektorowi i potrzebę opracowywania nowych profili kompetencyjnych. Do tych czynników dynamizujących dyskusje nad profilem kompetencyjnym dyrektora polskiej szkoły można także dołączyć postulaty formułowane na poziomie polityki europejskiej.

Sposób definiowania roli dyrektora szkoły ujawnia się poprzez projekty profili kompetencyjnych i w dalszej konsekwencji poprzez modele kształcenia i doskonalenia zawodowego dyrektorów. Ten wątek w kontekście porównawczym $\mathrm{w}$ odniesieniu do makropolityki przeanalizował i opisał Zbyszko Melosik ${ }^{14}$. W odniesieniu do polskiej szkoły warto zaakcentować

10 Tamże.

11 Tamże.

12 J. Pyżalski, Kompetencje przywódcze dyrektorów szkót i placówek w krajach Unii Europejskiej oraz w Stanach Zjednoczonych, Warszawa 2014, s. 11.

${ }^{13}$ S.M. Kwiatkowski, Tendencje zmian $w$ zarządzaniu oświata $w$ Polsce $i$ innych krajach Unii Europejskiej, [w:] Menedżer i kreator edukacji, red. Cz. Plewka, H. Bednarczyk, Radom 2008, s. 47.

${ }^{14}$ Zob. Z. Melosik, Systemy ksztatcenia i doskonalenia kadry kierowniczej. 
także znaczenie poziomu mezo. O ile programy studiów podyplomowych i kursów kwalifikacyjnych są projektowane przez ośrodki akademickie lub placówki kształcenia nauczycieli, o tyle rozwiązania ukierunkowane na doskonalenie aktywnych zawodowo dyrektorów to domena organów prowadzących. To na tym poziomie podejmowane są decyzje, w zakresie jakich kompetencji dyrektorzy mają poszerzać wiedzę i umiejętności. Tematyka oferty szkoleniowej projektowanej i finansowanej przez organy prowadzące może być interesującym wskaźnikiem preferowanego na tym poziomie sposobu pełnienia roli dyrektora.

Drugą wyodrębnioną przesłanką do namysłu nad projektami edukacyjnymi w zakresie rozwoju zawodowego dyrektora szkoły stanowią teoretyczne koncepcje rozwoju profesjonalnego. Pomocna może tu być, zaproponowana przez Davida Tuohy'ego, koncepcja podziału sfer rozwoju zawodowego nauczyciela na trzy poziomy - sferę ekstrapersonalną, sferę interpersonalną oraz sferę intrapersonalną ${ }^{15}$. Typologię tę można także z powodzeniem wykorzystać do projektu wspierania rozwoju zawodowego dyrektora szkoły.

Sfera ekstrapersonalna obejmuje aspekty techniczne, prawne i merytoryczne związane ze sprawowaniem funkcji. Każdy dyrektor powinien być ekspertem $\mathrm{w}$ zakresie stosowania prawa oświatowego oraz procedur obowiązujących w szkole. To właśnie sfery ekstrapersonalnej dotyczy większość szkoleń, kursów, warsztatów i konferencji dla dyrektorów. Szkolenia te odnoszą się najczęściej do zasad, procedur, systemów, programów i rozwiązań. Przykładem może tu być oferta edukacyjna odnośnie procedur egzaminów, zasad i technik ewaluacji, rozwiązań w zakresie budżetowania, programów informatycznych ułatwiających zarządzanie zasobami szkoły. Koresponduje ona najczęściej z menedżerskim aspektem pracy dyrektora. Sfera interpersonalna obejmuje kompetencje w obszarze interakcji społecznych. Są to przede wszystkim kompetencje dotyczące komunikowania się, motywowania, oceniania, mediowania, negocjowania, funkcjonowania w konfliktach. To one warunkują jakość realizowania zadań dyrektora i sprawność w zakresie budowania społeczności uczącej się. Są to kompetencje związane z realizacją roli przywódcy i lidera. Ta sfera objęta jest także ofertą szkoleniową, ale organizacja procesu rzeczywistego uczenia się i rozwoju w zakresie kompetencji społecznych jest trudna z przynajmniej dwóch powodów. Pierwszym jest kwestia definiowania i rozpoznawania kompetencji społecznych. Drugą kwestię stanowi problem poszukiwania propozycji rozwiązań metodycznych ukierunkowanych na rzeczywiste, a nie tylko

${ }^{15}$ D. Tuohy, Dusza szkoty. O tym, co sprzyja zmianie i rozwojowi, Warszawa 2002, s. 155. 
deklaratywne, kształtowanie, rozwijanie i wzmacnianie kompetencji $\mathrm{w}$ omawianym zakresie. Trzecia sfera - intrapersonalna - obejmuje poczucie sensu wykonywanej pracy oraz odczuwanie wewnętrznej satysfakcji. Jest ona także mocno związana $\mathrm{z}$ indywidualnymi wartościami i priorytetami dyrektora. Poczucie spełnienia i zadowolenia z wykonywanej pracy związane jest nie tylko $\mathrm{z}$ wewnętrznym odczuwaniem misji, ale także $\mathrm{z}$ tym, $\mathrm{w}$ jakim zakresie podejmowane działania korespondują $\mathrm{z}$ innymi zadaniami i sferami życia. Trudno zaplanować w tym obszarze ofertę edukacyjną. Treści z nim związane powinny obejmować takie zagadnienia, jak postawy wobec pracy i osób, z którymi się współpracuje, postrzeganie własnej roli zawodowej, redukowanie stresu i profilaktyka wypalenia zawodowego. Trudno nadać im formę szkolenia. Są to kwestie, z którymi każdy dyrektor powinien się zmierzyć indywidualnie, a podstawową formą pracy nad rozwojem $\mathrm{w}$ tym zakresie może być refleksja i namysł nad własnymi przekonaniami.

Analizując przesłanki do projektów edukacyjnych dla dyrektorów szkół, można także odnieść się do koncepcji współcześnie rozumianego profesjonalizmu oraz wybranych teorii andragogicznych. Bogusława D. Gołębniak analizując koncepcje Erica Hoyla, Lawrence'a Stenhousa, Donalda Schöna, Johna Elliotta, czy Delli Fish, dokonała rekonstrukcji cech nowego podejścia do profesjonalizmu realizowanego $\mathrm{w}$ środowisku szkolnym ${ }^{16}$. Autorka zwraca uwagę między innymi na napięcie pomiędzy modelem kompetencyjnym a filozofią refleksyjnej praktyki ${ }^{17}$. Napięcie to można odczytać także w postrzeganiu profesjonalnego wizerunku dyrektora szkoły. Pierwsza perspektywa opisuje zakres wiedzy i umiejętności w kategoriach technicznych. Dotyczy zarówno kwalifikacji, jak i koniecznych kompetencji rozumianych właśnie jako wiedza i umiejętności. Model refleksyjnej praktyki opisuje sposób działania w szkolnej codzienności i zdolność do oceny oraz interpretacji podejmowanych działań, jak też decyzji, by w dalszej kolejności - poprzez refleksyjny namysł - dokonywać zmian $\mathrm{w}$ kierunku postrzeganym jako konstruktywny. Refleksyjny praktyk uczy się poprzez analizę własnych działań. W odniesieniu do projektów edukacyjnych adresowanych do dyrektorów szkół można zauważyć jak mocne jest nawiązanie do modelu kompetencyjnego. Analizując chociażby zagadnienia związane z metodologią badań edukacyjnych, można odnotować wyraźne zorientowanie na badania sondażowe $\mathrm{i}$ ewaluacyjne projektowane $\mathrm{w}$ logice nadzoru i kontroli.

16 B.D. Gołębniak, Zmiany edukacji nauczycieli. Wiedza - biegłość - refleksyjność, Torun - Poznań 1998.

17 Tamże, s. 142. 
Kompetencje $\mathrm{w}$ zakresie badań jakościowych, metodologii action research i ewaluacji formatywnej są marginalizowane.

Namysł nad problemem ofert edukacyjnych ukierunkowanych na rozwój kompetencji dyrektora szkoły może być także przeprowadzony w perspektywie kształtowania kapitału profesjonalnego. Pojęcie to zaproponowali Andy Hargeaves i Michael Fullan w pracy Professional Capital. Transforming Teaching in Every School. W koncepcji tej kapitał profesjonalny jest funkcją kapitału ludzkiego, kapitału społecznego oraz kapitału decyzyjnego. Autorzy wskazują jednak na konieczność podkreślenia różnicy w zakresie interpretowania pojęcia kapitał ludzki w naukach ekonomicznych i w kontekście edukacyjnym. $\mathrm{O}$ ile na gruncie ekonomii jest on postrzegany jako „ekonomicznie wartościowa wiedza i kompetencje, które mogą być rozwijane w ludziach szczególnie poprzez edukację i szkolenia"18, o tyle w perspektywie pedagogicznej kapitał ludzki odnosi się bardziej do wiedzy i umiejętności, które pozwalają uczestniczyć, współtworzyć, uczyć się. Kapitał ludzki w ujęciu edukacyjnym daje możliwość odczytywania, interpretowania, wartościowania spraw, wydarzeń i trendów ważnych w perspektywie recentywistycznej. Kapitał społeczny to w opinii autorów przede wszystkim zasoby społeczne. Są one konieczne w procesie realizacji wszystkich zadań dyrekto$\mathrm{ra}^{19}$. Umiejętności $\mathrm{w}$ zakresie networkingu i efektywnej pracy zespołowej to kompetencje transferowalne, określają one sprawność $w$ zakresie nawiązywania i utrzymywania relacji zawodowych oraz korzystania z zasobów tkwiących w szeroko rozumianym otoczeniu społecznym. Cytowani autorzy wskazują także, poza kapitałem ludzkim i społecznym, na trzeci komponent kapitału profesjonalnego - kapitał decyzyjny. Jest on definiowany jako „zdolność do podejmowania samodzielnych osądów”20. Tak rozumiany kapitał związany jest z takimi kategoriami, jak: wewnątrzsterowność, proaktywność, refleksyjność, niezależność myślenia. Kapitał decyzyjny odnosi się zarówno do myślenia, jak i działania. Pozwala uniezależnić się od myślenia grupowego, sposobu interpretowania świata narzucanego przez media, grupy społeczne, ale także inne instytucje edukacyjne i rynek pracy.

Koncepcje współczesnego profesjonalizmu mogą być pomocne w namyśle nad projektami edukacyjnymi adresowanymi do dyrektorów. Poza wspomnianymi powyżej można także odwołać się do profili opracowywanych przez różne stowarzyszenia i organizacje oraz propozycji teorii wyjaśniających nie tylko rozwój profesjonalny, ale także aktywność edukacyjną

18 A. Hargreaves, M. Fullan, Professional Capital. Transforming Teaching in Every School, New York 2012, s. 89.

19 Tamże, s. 90.

20 Tamże, s. 93. 
uczących się dorosłych. Cechą wyróżniającą te ujęcia jest procesowe ujęcie rozwoju. Stąd można przyjąć założenie, że rozwój profesjonalny dyrektora szkoły także powinien mieć charakter procesowy i ustawiczny. Mając to na uwadze, warto zastanawiać się nad projektami ofert edukacyjnych dla dyrektorów szkół na trzech wskazanych poniżej poziomach. Pierwszy - podstawowy dotyczy kompetencji bazowych - społecznych i zawodowych. Można bowiem założyć, że - przynajmniej potencjalnie - każdy nauczyciel może w przyszłości zostać dyrektorem szkoły. Oznacza to, że w profesjonalnym kształceniu nauczycieli warto rozwijać postawy przywódcze, które w obszarze zachowań powinny obejmować przynajmniej katalog kompetencji związanych ze współpracą i rozwiązywaniem konfliktów, a w komponencie poznawczym uwzględniać takie zagadnienia, jak uwarunkowania realizowania polityki oświatowej na poziomie szkoły. Nawet jeśli dany nauczyciel nigdy nie podejmie zadań dyrektora, to można przyjąć, że ten podstawowy zestaw kompetencji ułatwi mu nawiązywanie współpracy z dyrektorem i rozumienie podejmowanych przez niego decyzji i działań. Drugi poziom to przygotowanie kandydatów do pracy na stanowisku dyrektora szkoły. Jest on w naszym systemie edukacyjnym rozwinięty najlepiej. Zadania w tym zakresie realizowane są poprzez wspomniane już kursy kwalifikacyjne i studia podyplomowe. Weryfikacji warto poddawać jednak proporcje między kształceniem do zadań menedżerskich a ofertą $\mathrm{w}$ zakresie kompetencji miękkich. Trzeci poziom to doskonalenie dyrektorów, którzy już tę funkcję pełnią. Program tej oferty edukacyjnej powinien wynikać z przyjętego i stale weryfikowanego profilu kompetencyjnego.

Opracowanie profilu kompetencyjnego stanowiącego podstawę do projektów rozwijających kompetencje czynnych zawodowo dyrektorów wymaga odniesienia się do aktualnych danych empirycznych, określających rzeczywiste zasoby kompetencyjne tej grupy. Dane te mogą $\mathrm{w}$ dalszej kolejności być konfrontowane z założeniami i postulatami teoretycznymi oraz oczekiwaniami innych podmiotów zaangażowanych - bezpośrednio lub pośrednio - w życie szkoły. Warto także zwrócić uwagę na formy doskonalenia dyrektorów szkół. Formuła studiów podyplomowych, głównie oparta na wykładach, wydaje się niewystarczająca. W odniesieniu do osób pełniących funkcję dyrektora ważne jest stworzenie bezpiecznej przestrzeni do ćwiczenia postulowanych zachowań oraz wymiany doświadczeń.

Podsumowując, chcę jeszcze raz zaakcentować, iż rozwoju w profesjonalnym wypełnianiu roli zawodowej nie utożsamiam $z$ ideą rozwijania kompetencji przywódczych, ani tym bardziej z formalnymi wymogami dotyczącymi przygotowania do podjęcia funkcji dyrektora szkoły. Rozwój profesjonalny jest procesem, a punktem odniesienia do projektów edukacyjnych 
wspierających ten rozwój powinny być - w mojej opinii - profile kompetencyjne negocjowane $\mathrm{z}$ różnymi podmiotami aktywnie zaangażowanymi w budowanie szkoły jako społeczności uczącej się. Dane empiryczne wskazują, iż grupy te mogą mieć odmienne (czasem sprzeczne) oczekiwania wobec dyrektorów i wyobrażenia dotyczące ich profesjonalizmu²1. We współczesnych rozwiązaniach edukacyjnych wydają się jednak dominować teorie opisujące przywództwo oraz ideologie formułowane na poziomie makropolityki. W praktyce oznacza to, iż postulaty edukacyjne projektowane są w oderwaniu od lokalnych uwarunkowań pracy dyrektora i szkoły. W perspektywie makropolitycznej preferowany profil dyrektora będzie podkreślał znaczenie kompetencji umożliwiających skuteczne pełnienie zadań administratora i menedżera dbającego o sprawne i efektywne realizowanie założeń, celów, wskaźników. Jeśli natomiast uwzględni się zadania wynikające z cech środowiska, w którym (i na rzecz którego) pracuje dyrektor, na znaczeniu będą zyskiwać kompetencje związane z umiejętnościami motywowania, mediowania i urzeczywistniania kultury partycypacji. W sytuacji, kiedy profil kompetencyjny dyrektora będzie nie tylko ustalony, ale także zaakceptowany przez społeczność szkolną, pytanie o możliwie najlepsze formy wspierania profesjonalnego rozwoju dyrektora pozwoli na poszukiwanie odpowiedzi daleko wykraczających poza tradycyjne studia podyplomowe i kursy.

\section{BIBLIOGRAFIA}

Bush T., From management to leadership: semantic or meaningful change? Educational Management, Administration and Leadership, 2008, 36(2).

Bush T., Theories of Educational Leadership and Management, Sage, London 2011.

Gołębniak B.D., Zmiany edukacji nauczycieli. Wiedza - biegłość - refleksyjność, Wydawnictwo Edytor, Torun - Poznań 1998.

Hallinger P., The evolving role of American principals: From managerial to instructional to transformational leaders, Journal of Educational Administration, 1992, 30, 3.

Hargreaves A., Fullan M., Professional Capital. Transforming Teaching in Every School, Routledge, New York 2012.

Kwiatkowski S.M., Tendencje zmian w zarządzaniu oświata w Polsce i innych krajach Unii Europejskiej, [w:] Menedżer i kreator edukacji, red. Cz. Plewka, H. Bednarczyk, Wydawnictwo Instytutu Technologii Eksploatacji, Radom 2008.

Madalińska-Michalak J., Skuteczne przywództwo w szkołach na obszarach zaniedbanych spotecznie. Studium porównawcze, Wydawnictwo Uniwersytetu Łódzkiego, Łódź 2012.

${ }^{21}$ Zob. M. Rosalska, Dyrektor szkoty - administrator, menedżer, przywódca. Między szkolna codziennością a polityką oświatową, Poznań 2016. 
Melosik Z., Systemy kształcenia i doskonalenia kadry kierowniczej w krajach Unii Europejskiej i Stanach Zjednoczonych, Ośrodek Rozwoju Edukacji, Warszawa 2014.

Ministerstwo Edukacji Narodowej, Ramowy plan i program kursu kwalifikacyjnego z zakresu zarządzania oświata, https://men.gov.pl/wp-content/uploads/2015/11/zatwierd zona-ramowka-kursu-z-zarzadzania-oswiata-w-pdf.pdf [dostęp: 02.01.2017].

Pyżalski J., Kompetencje przywódcze dyrektorów szkót i placówek w krajach Unii Europejskiej oraz w Stanach Zjednoczonych, Ośrodek Rozwoju Edukacji, Warszawa 2014.

Rosalska M., Dyrektor szkoły - administrator, menedżer, przywódca. Między szkolna codziennością a polityką oświatowa, Wydawnictwo Naukowe UAM, Poznań 2016.

Rozporządzenie Ministra Edukacji Narodowej z 8 listopada 2011 roku zmieniające rozporządzenie w sprawie wymagań, jakim powinna odpowiadać osoba zajmująca stanowisko dyrektora oraz inne stanowisko kierownicze $\mathrm{w}$ poszczególnych typach publicznych szkół i rodzajach publicznych placówek, DzU 2011, 254, 1526.

Tuohy D., Dusza szkoty. O tym, co sprzyja zmianie $i$ rozwojowi, Wydawnictwo Naukowe PWN, Warszawa 2002.

Więsław Sz., Sytuacja i status zawodowy dyrektorów szkót i placówek oświatowych, Ośrodek Rozwoju Edukacji, Warszawa 2012. 